\title{
The Fast Breeder Reactor
}

Need? Cost? Risk?

Edited by

Colin Sweet 
(C) The contributors 1980

Softcover reprint of the hardcover 1st edition 1980 978-0-333-27973-1

All rights reserved. No part of this publication may be reproduced or transmitted, in any form or by any means, without permission

First published 1980 by

THE MACMILLAN PRESS LTD

London and Basingstoke

Associated companies in Delhi Dublin

Hong Kong Johannesburg Lagos Melbourne

New York Singapore and Tokyo

Typeset by

Reproduction Drawings Ltd, Sutton, Surrey

\section{British Library Cataloguing-in Publication Data}

The fast breeder reactor.

1. Fast reactors-Economic aspects-Congresses

2. Fast reactors--Social aspects-Congresses

I. Sweet, Colin

338.4'7'6214834 HD9698.AQ

ISBN 978-1-349-81393-3 ISBN 978-1-349-81391-9 (eBook)

DOI 10.1007/978-1-349-81391-9

This book is sold subject to the standard conditions of the Net Book Agreement 


\section{Contents}

The Contributors

Acknowledgements

Abbreviations Used in the Text

Introduction Colin Sweet

PART I: The Fast Breeder in Energy Policy

1. Energy Perspectives for the UK Leslie Grainger

2. Some Policy Aspects of the Fast Reactor Question John Surrey 23

3. The Electricity Sector and Energy Policy Peter Odell 31

4. A Low-Energy Growth Alternative Gerald Leach 41

5. Technology and Energy Supply Meredith W. Thring 49

PART II. Risk and Uncertainty

6. Fast Reactors and Problems in Their Development Norman Dombey 61

7. Part 1: The Assessment and Assumptions of Risk with Fast Reactors Peter J. Taylor

Part 2: An Alternative View-Some Safety Considerations of the Fast Breeder Reactor F. R. Farmer

8. The UK Fast Breeder Programme Walter Marshall

9. Radiation Hazards: Areas of Uncertainty Patricia J. Lindop

PART III: Economic Appraisals

10. The Economics of Coal and Nuclear Power Plants Michael J. Prior

11. Nuclear Power Economics P.M. S. Jones

12. Critique of the Economic Case for the Fast Reactor Colin Sweet

PART IV: Political Problems of Fast Reactors

13. Plutonium and Proliferation Problems Bhupendra Jasani

14. Nuclear Power and Civil Liberties David Widdicombe 


\section{Appendices}

Appendix 1 UK Energy Needs and Energy Supply

Appendix 2 Alternative Ways of Calculating the Future Use of Energy in Coal Equivalent Terms. A Note by Professor Peter Odell 211

Appendix 3 The Breeding Principle and Fast Reactors

Appendix 4 Energy Policy Matrix

Appendix 5 A Potential Fast Breeder Accident at Kalkar. A Summary of a Recent PERG Study

Index 


\section{The Contributors}

Norman Dombey, Reader in Theoretical Physics, University of Sussex

F. R. Farmer, Safety Adviser to the Atomic Energy Authority; Visiting Professor at Imperial College, London

Leslie Grainger, Formerly Chairman, IEA (Coal Services) Limited

Dr Bhupendra Jasani, Stockholm International Peace Research Institute

Dr P. M. S. Jones, Head of Economics and Programmes, Atomic Energy Authority, London

Gerald Leach, Senior Research Fellow, Institute of Environment and Development (with F. Romig, A. Van Buren and G. Foley, co-author of Low Energy Strategies)

Patricia J. Lindop, Professor of Radiobiology at St Bartholomew's Hospital Medical School, London (Member of the Royal Commission on Environmental Pollution)

Walter Marshall, CBE, FRS, Deputy Chairman of the Atomic Energy Authority (formerly Chief Scientist at the Department of Energy)

Peter Odell, Professor of Economic Geography, Erasmus University, Rotterdam (author of many studies on oil)

Michael J. Prior, Formerly Economist with the International Energy Agency (Coal Reseach), London; presently Senior Consultant, Environmental Resources Ltd

John Surrey, Senior Research Fellow, Science Policy Research Unit, Sussex University (with Lesley Cook, co-author of Energy Policy: Strategies for Uncertainty)

Colin Sweet, Senior Lecturer in Economics, Polytechnic of the South Bank, London

Peter J. Taylor, Research Student, Institute of Social Anthropology, University of Oxford; Co-director of the Political Ecology Research Group Ltd

Meredith W. Thring, Professor (and Head of Department) of Mechanical Engineering, Queen Mary College, University of London

David Widdicombe, QC, Chairman of the Administrative Law Committee of Justice 


\section{Acknowledgements}

Acknowledgements are made to the Director and staff of the Polytechnic of the South Bank, London, SE1, where the conference on which this book is based was held on 23-24 November 1978. 


\section{Abbreviations Used in the Text}

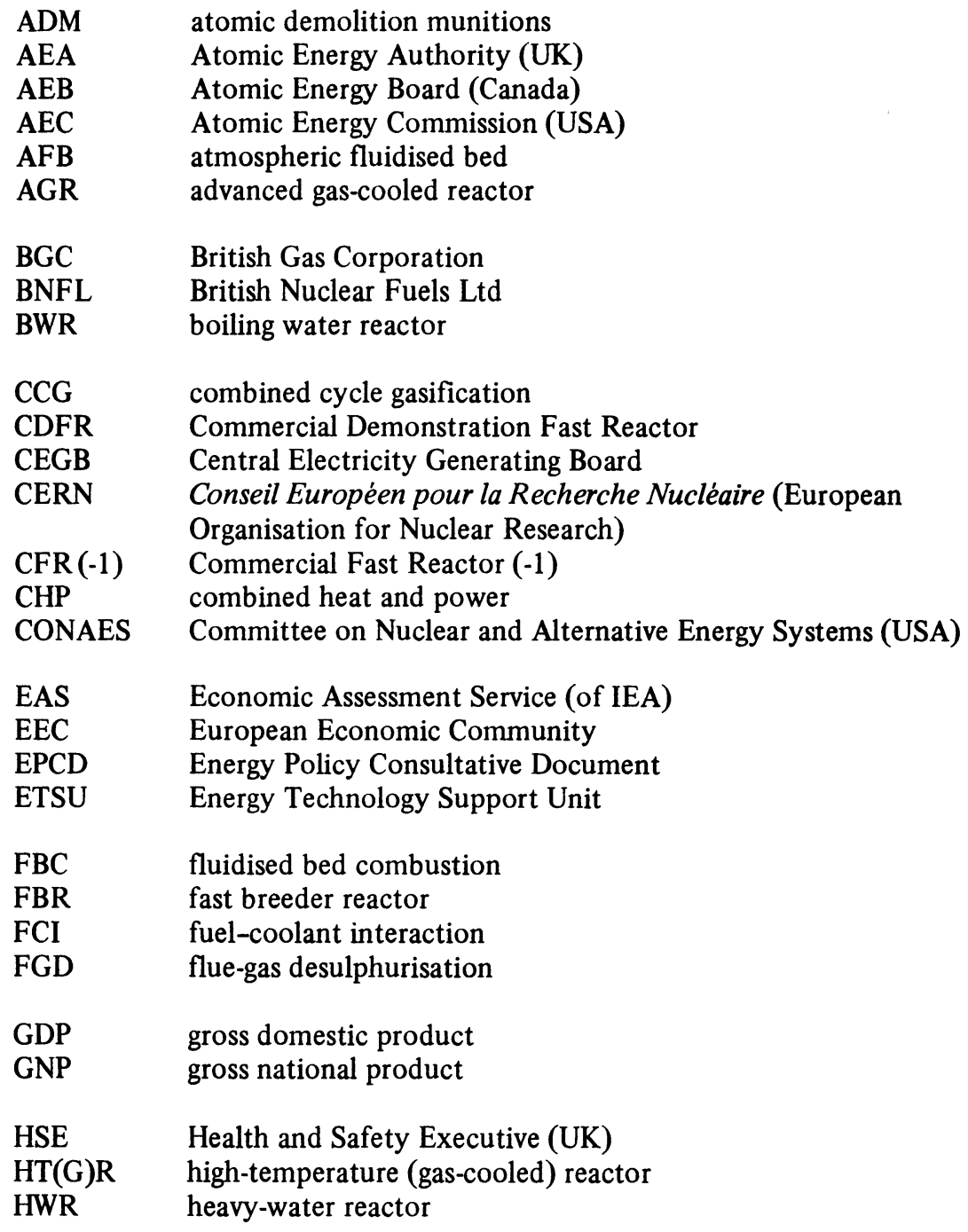




\begin{tabular}{|c|c|}
\hline IAEA & International Atomic Energy Agency . \\
\hline ICRP & International Commission on Radiological Protection \\
\hline IEA & International Energy Agency \\
\hline IIASA & International Institute of Applied Systems Analysis \\
\hline INFCE & International Nuclear Fuel Cycle Evaluation \\
\hline JET & Joint European Torus \\
\hline LMFBR & liquid-metal fast breeder reactor \\
\hline LWR & light-water reactor \\
\hline MRC & Medical Research Council \\
\hline NCB & National Coal Board \\
\hline NII & Nuclear Installations Inspectorate (UK) \\
\hline NNC & National Nuclear Corporation \\
\hline NPT & Non-Proliferation Treaty (of nuclear weapons) \\
\hline NRC & Nuclear Regulatory Commission (USA) \\
\hline NRPB & National Radiological Protection Board \\
\hline OECD & Organisation for Economic Cooperation and Development \\
\hline OPEC & Organisation of Petroleum-Exporting Countries \\
\hline $\begin{array}{l}\text { PERG } \\
\text { PF }\end{array}$ & $\begin{array}{l}\text { Political Ecology Research Group } \\
\text { pulverised fuel }\end{array}$ \\
\hline PFB & pressurised fluidised bed \\
\hline PFR & Prototype Fast Reactor \\
\hline PNE & peaceful use of nuclear explosives \\
\hline PWR & pressurised water reactor \\
\hline $\begin{array}{l}\text { RCEP } \\
\text { R \& D }\end{array}$ & $\begin{array}{l}\text { Royal Commission on Environmental Pollution } \\
\text { research and development }\end{array}$ \\
\hline SALT & Strategic Arms Limitation Treaty \\
\hline SNG & synthetic natural gas \\
\hline SSEB & South of Scotland Electricity Board \\
\hline THORP & Thermal Oxide Reprocessing Plant \\
\hline UKAEA & United Kingdom Atomic Energy Authority \\
\hline UNSCEAR & $\begin{array}{l}\text { United Nations Scientific Committee on the Effects of Atomic } \\
\text { Radiation }\end{array}$ \\
\hline
\end{tabular}

